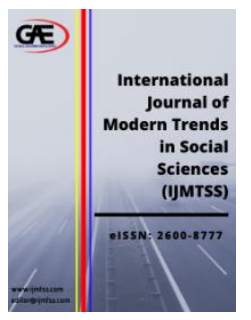

\author{
INTERNATIONAL JOURNAL OF \\ MODERN TRENDS IN \\ SOCIAL SCIENCES \\ (IJMTSS) \\ WWW.ijmtss.com
}

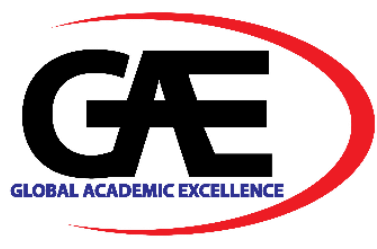

\title{
IMPACTS OF DESIGN THINKING COURSE FOR UNDERGRADUATE STUDENTS IN A PRIVATE HIGHER EDUCATION INSTITUTION
} \author{
Chia Wei ${ }^{4 *}$ \\ 1 Centre of Liberal Arts and Language, INTI International University, Malaysia \\ Email: menaga.vesudevan@newinti.edu.my \\ 2 Centre of Liberal Arts and Language, INTI International University, Malaysia \\ Email: intanmohmadrozee@newinti.edu.my \\ 3 Centre of Liberal Arts and Language, INTI International University, Malaysia \\ Email: noorfarah.shamsuddin@ newinti.edu.my \\ 4 Centre of Liberal Arts and Language, INTI International University, Malaysia \\ Email: chiawei.lim@newinti.edu.my \\ * Corresponding Author
}

Menaga Vesudevan ${ }^{1 *}$, Intan Syafinaz Mohd Rozee ${ }^{2 *}$, Wan Noor Farah Wan Shamsuddin ${ }^{3 *}$, Lim

\section{Article Info:}

Article history:

Received date:07.09.2020

Revised date: 08.09.2020

Accepted date: 10.09 .2020

Published date: 15.09.2020

\section{To cite this document:}

Vesudevan, M., Rozee, I. S. M., Shamsuddin, W, N, F, W., \& Lim, C. W. (2020). Impacts Of Design Thinking Course For Undergraduate Students In A Private Higher Education Institution. International Journal of Modern Trends in Social Sciences, 3 (13), 39-45.

DOI: 10.35631/IJMTSS. 313004
Abstract:

The general idea behind any Design Thinking course is to expand the creativity and critical thought process of students in their studies and develop these highly sought after skillsets at the tertiary level. In this study, the Design Thinking course helps students to develop practical and innovative solutions based on the problems that figured and need to have a solution. This research explores the impacts of the Design Thinking course for undergraduate students in a private institution in Negeri Sembilan, Malaysia. This research was conducted with the use of a quantitative research method through an online survey and was distributed to 114 students at the end of the course. This was done to examine the impacts of the Design Thinking course. Furthermore, the survey questionnaire was used as the main tool for data collection. The findings show a positive impact of the Design Thinking course for undergraduate students, the course has given a great platform to students and having a design thinking mindset to think more creatively.

Keywords:

Design Thinking Method, Sustainable Development Mindset, Brainstorming And Collaboration Skills 


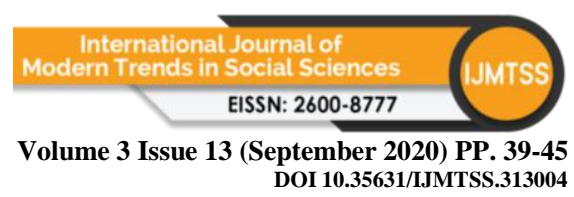

\section{Introduction}

In recent years, Design Thinking has become more and more important by expanding its fields of application in education studies. Creativity can be seen through students creative design product creation. Besides, the Design Thinking course encourages students to use high-level of cognitive skills and benefits students in a variety of ways such as bolstering collaboration among the team members, the insightful of creativity and proving a meaningful context (Koh, Chai, Wong, \& Hong, 2015). Furthermore, Design Thinking course, students are required to develop practical and innovative solutions to a real business or socio-political issues (Rotherham \& Willingham, 2009). Therefore, its helps student succeeds in this interconnected of digital world and educators support students in developing and honing 21 st-century skills, such as Design Thinking, systems thinking, and collaborative skills that enhance their problemsolving skills and prepare them for future professionals (Rotherham \& Willingham, 2009; Shute \& Torres, 2012). The Design Thinking course covers a solid understanding of the Design Thinking process and teaches students how to systematically extract, learn and apply humancentric techniques in solving problems innovatively.

\section{Literature Review}

\section{Design Thinking Method}

The Design Thinking process is characterized by principles and methods of designing a new product by following the Design Thinking process. Hence, it is the design state of mind and the behaviours that show by the students creative in innovation through their teamwork to enable the process and activities of Design thinking (Sobel and Groeger, 2013b). Thus, we focus the importance of principles, the Design Thinking creating a creative mindset approaches to solve problems, to explore greater strategies, inspire greater product and service of innovation (Martin and Euchner, 2012). Design Thinking course uses the Design Thinking process to solve the issues by creating a creative design. However, the principle of Design Thinking works iteratively in design thinking cycles. Whenever a solution idea has been tested, questions will be posed about whether it contributes to a solution for the original problem brief and whether the initial problem brief was the right one (Guay 2018). This knowledge enables the development of extremely customer-oriented solution ideas. Following with Design Thinking needs a special place to conduct Design Thinking projects successfully, special spaces are required: designed according to the teams' needs and equipped with the right materials. 


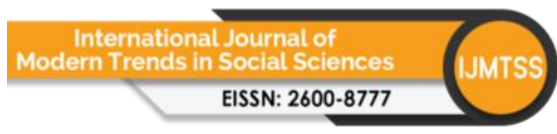

Volume 3 Issue 13 (September 2020) PP. 39-45

DOI 10.35631/IJMTSS.313004

\section{Design Thinking Processes with A Sustainable Development Mindset}

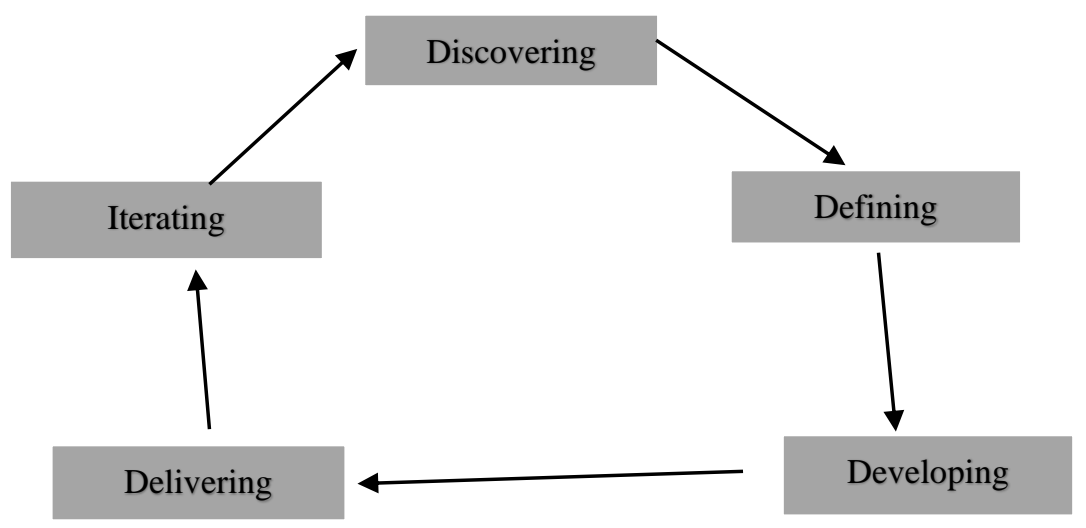

Figure 1: Design Thinking Process

Source: (Design Thinking 101—Neilsen Norman Group)

The Design Thinking course implements Design thinking processes with a sustainable development mindset, there are five main phases (refer to Figure 1.0). Once teams are formed, the first stage of this process is the discovering phase, where students research current issues such as those laid out by the Sustainability Development Goals SDGs. These research studies can be grouped into primary and secondary research, which helps students narrow down their focus to what they would like to find a solution for. The following stage is the defining phase where students define an actionable problem statement by creating a design challenge proposal and are expected to clearly explain the targeted issue they will be focusing on. Students may also include specific communities or groups and insights that they have uncovered during the discovering stage. At this stage, they would not yet provide any particular solution - the focus is purely on getting students to develop a good grasp of the issues. The developing phase is when awareness turns into actually solving the problem. In this phase, students will work towards a creative solution for the issues they have discovered and defined. Thus, students are also assigned to mentors from the industry who work with them to connect their ideas more closely to business and socio-economic realities. These experienced mentors also guide students in developing a creative prototype which addresses the problem they have identified. The next phase is delivering, where students begin building a prototype of their project solution. The sorts of prototypes that students may use could be applications or 3D models that provide an actual look and feel for their solution. A well-designed prototype should focus on demonstrating visual design, content and interactivity. With their prototype created, students will need to assess whether or not their solution/prototype has answered their problem statement. Lastly, the final phase is iterating, where students present their ideas and their prototype before an audience in university this includes industry leaders, which creates a truly realistic and professional space that facilitates practical learning. Students collect feedback from their audience through the use of a feedback grid. This helps them to organize and improve on the product or service they have proposed according to their audience - which mimics real customer needs. Throughout the Design Thinking process, it leads to innovate in sustainable development, the Design Thinking process is useful to innovate new ideas and to improve the quality of the environment (Brown, 2009). Through these five stages, students develop design thinking skills while also immersing themselves in sustainable development (Dam \& Siang, 2018). 


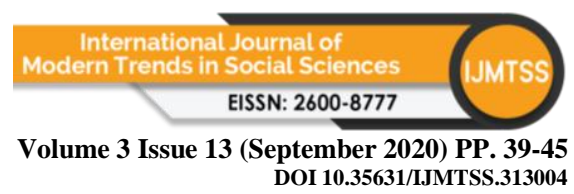

This research is to study the impacts of design thinking course for undergraduate students. The objectives of this research is:

- To determine the benefits of design thinking course for undergraduate students.

\section{Brainstorming And Collaboration Skills}

The design thinking course encourages students to brainstorm ideas among their team members, as it helps the students to generate more innovative ideas. Design Thinking team builds up knowledge and experience about the problem, which form brainstorming and collaboration skills. Hence, it encourages students to generate a large number of ideas and produce different options for solving the challenges. However, Van der Lugt (2002) mentioned that brain sketching approach is a better technique when collaborating with a group member to build and generate ideas among the team members. In addition, the group brainstorming shows the most optimal process for generating the most ideas among the team and collaborate the collected ideas through discussion (Korde \& Paulus, 2017). In higher education, brainstorming shows an essential element for students to develop understanding and contribute their ideas through effective group discussions (Egan, Maguire, Christophers, \& Rooney, 2017). Through the brainstorming, it's form techniques where it fosters the group creativity, by collaborating ideas and thoughts are shared among members spontaneously in order to reach solutions to practical problems (Gogus, 2012). However, this has led to the application of various methods in many studies in order to foster creative thinking skills among university students through idea generation (Kelly, 2016; Montag-Smit \& Maertz, 2017).

\section{Methodology}

In this study, data analysis involves the use of statistical methods of descriptive statistics. This research was conducted at a private university in Negeri Sembilan, to analyze the impacts of Design Thinking course among the undergraduate students. A set of the questionnaire is developed which has 5 points Likert scale approach. It is used to assess students expression on how much they agree or disagree with a particular statement. The data collected through an online survey from 114 students of various disciplines. The online survey is divided into two sections which are section $\mathrm{A}$ and section $\mathrm{B}$, section $\mathrm{A}$ is the demographic information and section B involves 15 statements of the use of Design Thinking course for undergraduate students. Throughout this study, the descriptive study provides a sample of information about the scenario as well as the current situation which happened at a particular time. Purposive sampling is used, and it is a sampling procedure where a group of subjects having certain characteristics are interested to be studied.

\section{Findings and Analysis}

The research objective is:

To determine the use of Design Thinking course for undergraduate students. 
Table 1: Mean and Standard Deviation of Design Thinking Course for Undergraduate Students

\begin{tabular}{ccc}
\hline Information & $\begin{array}{c}\text { Mean } \\
(M)\end{array}$ & $\begin{array}{c}\text { Std. } \\
\text { Deviation } \\
\text { (SD) }\end{array}$ \\
\hline
\end{tabular}

1. Design thinking course emphasizes on my logic and

$4.14 \quad 0.664 \quad$ High
reasoning skills.

2. Design thinking course allows me to explore things from different perspectives.

$4.13 \quad 0.770 \quad$ High

3. Practising Design Thinking develops my ability in $4.20 \quad 0.800 \quad$ High creating new ideas.

4. Design thinking course allows me to examine a handson learning and develop my Design Thinking capacity.

5. I would say Design Thinking subject is a good platform for students' talent and creativity.

6. The concept of Design Thinking processes does not $4.09 \quad 0.830$ High only allow me to grasp the ideas easier, but also engage me throughout the process.

7. I practice Design Thinking process through discovery, creative problem solving and implement ideas through prototype.

8. I am confident in developing my design thinking ideas using Design Thinking methods and processes.

4.13 $0.836 \quad$ High

4.20 $\quad 0.811 \quad$ High

$3.82 \quad 0.885 \quad$ High

9. Design thinking course shows my ability, enthusiasm, $\quad 4.00 \quad 0.852 \quad$ High creativity, talents and inventiveness.

10. Design thinking course is a powerful course in adding values in my character, skills and learning to learn (curiosity).

11. Design Thinking course combines hands on exploration with opportunities to apply and test the knowledge that

$4.11 \quad 0.791$

High I gained from the course.

12. Design thinking encourages me to know some things and makes me to explore as much as I can.

$4.01 \quad 0.877 \quad$ High

13. Brainstorming and collaboration skills are valuable skills in design thinking course.

4.16 $0.888 \quad$ High


14. Design thinking course allows me to work with my team by exchanging feedback and ideas.
$4.24 \quad 0.823 \quad$ High

4.12 $\quad 0.914 \quad$ High

\begin{tabular}{l}
$\begin{array}{l}\text { 15. I used Design Thinking processes to create our team's } \\
\text { prototype. }\end{array}$ \\
\hline Overall
\end{tabular}

Based on the table above (Table 1), shows the score of the use of the Design Thinking course for undergraduate students. Overall, the findings show the positive impacts of the Design Thinking course for undergraduate students. Like a shred of evidence, the overall mean for 15 statements scored 4.10 point. The highest mean score are from the item 3 and item 5, practising design thinking develops my ability in creating new ideas $\mathrm{M}=4.20$, SD 0.800 , and I would say design thinking subject is a good platform for students' talent and creativity M=4.20, SD 0.811. moreover, the closely related mean scored from item 13, Brainstorming and collaboration skills are valuable skills in design thinking course $\mathrm{M}=4.16$, SD 0.888 . Besides, the lowest mean score is from item 7 , I practice design thinking process through discovery, creative problem solving and implement ideas through the prototype $\mathrm{M}=3.82$, SD 0.885 . From the overall analysis the Design Thinking course really benefited for undergraduate students it shows at the high level of the mean score. Through the analysis its shows that design thinking course is to expand the creativity and critical thought process of students in their studies and develop these highly sought-after skillsets. Furthermore, working collaboratively as a team to identify the problems and conduct research broadens the amount of information gathered, facilitates discourse and brings together multiple perspectives when developing a solution.

\section{Conclusion}

Based on the results, this study reveals that the Design Thinking course is beneficial for undergraduate students. Moreover, Design thinking course shows the creativity and critical thought process of students in their studies and develop these highly sought-after skillsets. Design thinking course is human-focused, prototype-driven, and inculcates skills throughout the programme (Jin \& Chusilp, 2006). It enables students to immerse themselves into the realities impacting organisations and societies at large, and when paired with global issues such as those emphasized by the United Nations Sustainable Development Goals (SDGs), offers a holistic learning experience. Thus, the Design Thinking process also applied throughout the creation and innovation of products, services, systems, procedures, protocols and user experiences. Through the study it shows, students begin by generating ideas and then pairing these with sustainable solutions. Experiencing these five phases firsthand and gaining inputs from academics and industry throughout their module immerses students into how to use the methods, strategies and design process to achieve better outcomes - both in the classroom and as a lifelong skill (Dunne 2018). This helps them to learn that in tackling any form of challenge, sustainability and long-term impact must be assessed carefully. As a constructive learning strategy, incorporating design thinking into higher education curricula empowers students to become more open to ideas and to innovate better solutions. Coupled with the meaningful discourse that incorporates social development like the SDGs, this subject is an excellent means for students to develop a range of skills and gain holistic insights that will support them in achieving their future aspirations. 


\section{References}

Brown, T., 2009. Change by design: How design thinking transforms organizations and inspires innovation, Harper Collins. New York

Dam, R., Siang, T. (2018). 5 stages in the design thinking process. Retrieved from https://www.interaction-design.org/literature/article/5-stages-in-the-design-thinkingprocess.

Dunne D (2018) Design thinking at work: how innovative organizations are embracing design. University of Toronto Press, Toronto.

Egan, A., Maguire, R., Christophers, L., \& Rooney, B. (2017). Developing creativity in higher education for 21st century learners: A protocol for a scoping review. International Journal of Educational Research, 82, 21-27.

Gogus, A. (2012). Brainstorming and learning Encyclopedia of the sciences of learning. Springer484-488.

Guay J (2018) How Denmark lost its MindLab: the inside story. https://apolitical.co/solution_article/how-denmark-lost-itsmindlab-the-inside-story/. Accessed 5 Nov 2018.

Jin, Y., \& Chusilp, P. (2006). Study of mental iteration in different design situations. Design Studies, 27(1), 25-55.

Kelly, R. (2016). Engaging in creative practice: From design thinking to design doing. Creative Development: Transforming Education Through Design Thinking, Innovation, and Invention, 57.

Koh, J. H. L., Chai, C. S., Wong, B., \& Hong, H.-Y. (2015). Design thinking for education. Singapore: Springer Science+Business Media.

Korde, R., \& Paulus, P. B. (2017). Alternating individual and group idea generation: Finding the elusive synergy. Journal of Experimental Social Psychology, 70, 177-190.

Martin, R. and Euchner, J., 2012. Design thinking. Research-Technology Management, 55(3), pp.10-14

Razzouk, R., \& Shute, V. (2012). What is design thinking and why is it important? Review of Educational Research, 82(3), 330-348.

Rotherham, A. J., \& Willingham, D. (2009). To work, the 21 st century skills movement will require keen attention to curriculum, teacher quality, and assessment. Educational Leadership, 9, 15-20.

Sobel, L. \& Groeger, L. 2013b. The Future of Design Thinking in Australia. Design Management Review, 24, 26-31.

Shute, V. J., \& Torres, R. (2012). Where streams converge: Using evidence-centered design to assess Quest to Learn. In M. Mayrath, J. Clarke-Midura, \& D. H. Robinson (Eds.), Technology-based assessments for 21st century skills: Theoretical and practical implications from modern research (pp. 91-124). Charlotte, NC: Information Age Publishing.

Van Der Lugt, R. (2002). Brainsketching and how it differs from brainstorming. Creativity and Innovation Management, 11(1), 43-54. 